\title{
Homogeneous microbial diversity in the upper sediment layers of a shallow lake
}

\author{
N. Tšertova ${ }^{1}$, A. Kisand ${ }^{2,3}$, F. Baty ${ }^{4}$, V. Kisand ${ }^{1,2, *}$ \\ ${ }^{1}$ University of Tartu, Institute of Technology, Tartu 50411, Estonia \\ ${ }^{2}$ Estonian University of Life Sciences, Centre for Limnology, Tartu 50411, Estonia \\ ${ }^{3}$ Institute of Geology, Tallinn University of Technology, Tallinn 19086, Estonia \\ ${ }^{4}$ Pneumology, Cantonal Hospital, St. Gallen 9007, Switzerland
}

\begin{abstract}
The variability and patchiness in composition of bacterial communities were studied in a large eutrophic boreal lake $\left(280 \mathrm{~km}^{2}\right)$ with a mean depth of $<3 \mathrm{~m}$. The present study was undertaken to determine the factors that influence species dispersal in the sediment environment of large shallow lakes and to test the hypothesis that species dispersal in the sediment is heterogeneous. Surficial sediment samples were collected according to both transect and 'log-wise' sampling designs. For the vertical slicing of sediment samples, steps were chosen according to average deposition rates. Bacterial community composition (BCC) was examined by denaturing gradient gel electrophoresis (DGGE) of PCR amplification products from DNA extracted from the total community. The relationships of the DGGE fingerprint to space, bacterial abundance, production, and dry weight of the sediment were analyzed using multivariate statistical methods. The $\mathrm{BCC}$ was found to be uniform over both the 1 to $1000 \mathrm{~m}$ ('log-wise') and kilometer (>10 km transect) scales. An increase in bacterial diversity from the river bed to mid-lake corresponded to the sediment type and was related to an increase in productivity. Vertically, the bacterial diversity decreased with sediment depth while the bacterial community in the upper 2 to $5 \mathrm{~cm}$ of sediment was almost homogeneous. These data suggest that $\mathrm{BCC}$ of organic-rich sediment is very homogeneous horizontally, and the upper centimeters of the sediment undergo frequent mixing, leading to similar homogeneity.
\end{abstract}

KEY WORDS: Large lake $\cdot$ Bacterial community composition $\cdot$ 16S rDNA PCR-DGGE $\cdot$ Horizontal distribution $\cdot$ Vertical distribution $\cdot$ Habitat homogeneity $\cdot$ Multiple factorial analysis

\section{INTRODUCTION}

Sediment bacteria play an important role in organic matter decomposition, nutrient cycling, and benthic food webs, and usually affect several gross system processes in water bodies (e.g. consumption of oxygen, consumption or release of nutrients; Güde et al. 2004, Schultz \& Urban 2008, Skoog \& AriasEsquivel 2009). In shallow lakes and coastal marine areas, the sediment environment interacts even more closely with the water column than it does in any other aquatic ecosystem, and is integrated into the whole system more directly. Therefore, studies of these ecosystems should incorporate both the water column and the sediment environment (Spears et al. 2007, Niemistö et al. 2008).

It is clear that various processes can influence the distribution of various organisms including bacteria when water column is compared with sediment. Prior to the holistic study of an ecosystem, it is necessary to determine the scales of variability in distribution, and to evaluate how common the patterns are across space and time. This has immediate practical value in shallow water bodies; however, it is not always clear 
how to design a sampling strategy that is able to detect important ecological processes that operate over different spatial scales and environments.

Large shallow lakes could represent a good experimental system to study the processes that occur in other important water systems, such as shallow marine coasts (estuaries, lagoons, etc.), because various complex interactions, such as wind-driven resuspension, tides, open boundaries, etc., are often relevant in shallow lakes. To our knowledge, the influence of strong wind-driven resuspension on the distribution of the bacterial community in space and time within the sediment has not been studied in water bodies with a long wind fetch of several kilometers and a shallow water column $(\sim 2 \mathrm{~m})$ (Bloesch 1995, Kelderman et al. 2012). Because of this gap in the literature, the patchiness and dynamic movement of the bacterial community composition (BCC) in the sediments of shallow lakes (both vertically and horizontally) remain unknown. Potentially, intensive resuspension events could continually homogenize the upper layers of lake deposits both vertically and horizontally; however, there could be many influencing factors such as the bottom bathymetry and patchiness of submerged vegetation. The depth at which resuspension potentially affects the BCC has also not been very well studied. In a previous experiment, we studied the temporal variation in surficial $(<1 \mathrm{~cm})$ sediment over a $1 \mathrm{yr}$ period (Tšertova et al. 2011); however, spatial variation was not incorporated in that study.

The goal of the present study was to gain insight into the spatial heterogeneity of the bacterial community in surficial sediments $(<20 \mathrm{~cm})$ of a large shallow lake. Sediment patchiness in large lakes is presumably higher compared with smaller lakes and therefore a higher resolution sampling strategy and different experiments might be needed to understand processes that occur on the scale of the entire lake. For this, we sampled the horizontal variation in the sediment at various scales from $\sim 1 \mathrm{~m}$ to several kilometers and the vertical depth gradient from the water-sediment interface to a depth of $20 \mathrm{~cm}$.

\section{MATERIALS AND METHODS}

\section{Study area and sediment sampling}

The eutrophic Lake Võrtsjärv is situated in southern Estonia at $57^{\circ} 50^{\prime}$ to $58^{\circ} 30^{\prime} \mathrm{N}$ and $25^{\circ} 35^{\prime}$ to $26^{\circ} 40^{\prime}$ E. Lake Võrtsjärv has a large area $\left(280 \mathrm{~km}^{2}\right)$ and is shallow (mean depth $2.8 \mathrm{~m}$, maximum depth

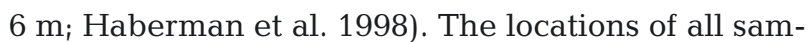
pling sites are shown in Fig. 1 and sampling times and resolution are presented in Table 1.

Sediment samples were collected using a Willner sediment corer. The cores were transported to the laboratory in a light-tight insulated box for further processing, usually within 0.5 to $3 \mathrm{~h}$. They were sliced to obtain the following layers: $0-0.5,2-3,5-6$, $10-11,15-16$, and $20-21 \mathrm{~cm}$ (depth margins counted down from the sediment surface). These slicing intervals were chosen according to the average deposition rates in this lake (Heinsalu et al. 2008). The slices were used to assess the vertical distribution (depth

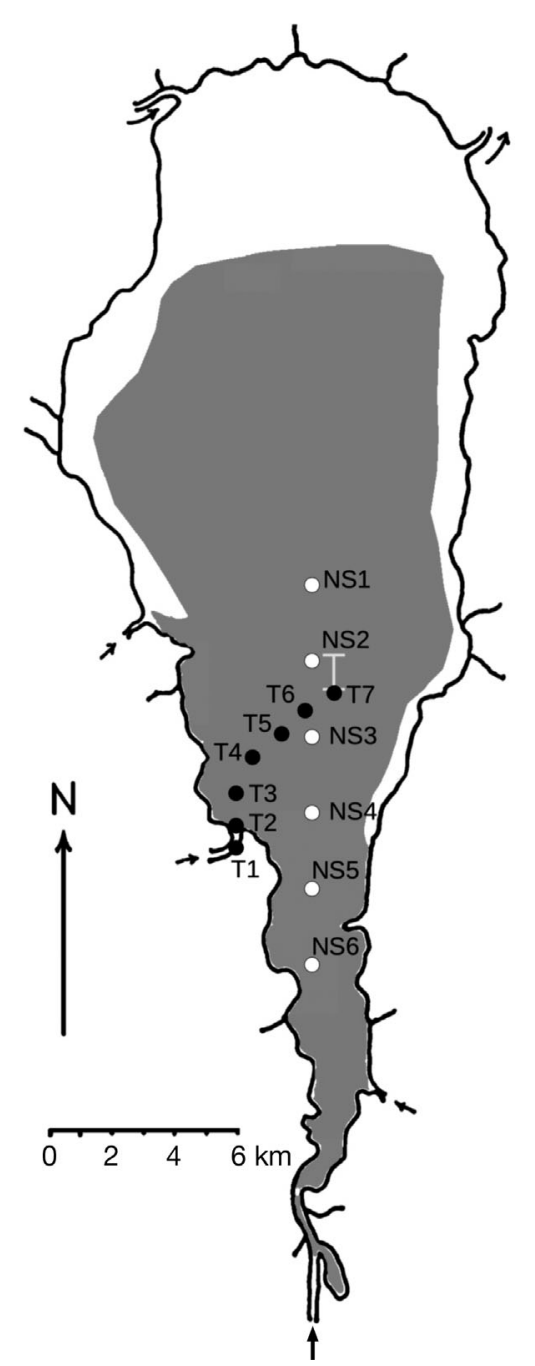

Fig. 1. Simplified map of lake sediment (only area covered by sapropel indicated: two thirds of area, grey shading), and sampling stations used in the present study. Stns T1 to T7 are the river to lake sampling points. Stn T7 overlaps with the depth profile (DP) and small to large spatial scale (EXP) sampling sites (white bar). The north to south transect survey was conducted at Stns NS1 to NS6 
Table 1. Detailed description of sampling design, resolution, dry weight (DW), total number of bacteria (TNB) and bacterial production (BP). n: number of sediment cores collected during sampling campaign; NA: not available; WW: wet weight

\begin{tabular}{|c|c|c|c|c|c|}
\hline $\begin{array}{l}\text { Sampling campaign } \\
\text { (ID) }\end{array}$ & $\begin{array}{l}\text { Time } \\
\text { (n) }\end{array}$ & $\begin{array}{l}\text { Interval } \\
\text { (direction) }\end{array}$ & $\begin{array}{c}\text { DW (g DW } \\
\left.g^{-1} \mathrm{WW}\right)\end{array}$ & $\begin{array}{c}\text { TNB }\left(10^{9}\right. \\
\left.\text { cells } \mathrm{g}^{-1} \mathrm{DW}\right)\end{array}$ & $\begin{array}{c}\mathrm{BP}(\mu \mathrm{g} C \\
\left.\mathrm{g}^{-1} \mathrm{DW}\right)\end{array}$ \\
\hline Depth profiles (DP) & 2005 to 2006 (10) & Centimeters (vertical) & $5.5 \pm 1.9$ & $1.80 \pm 1.04$ & $3.9 \pm 3.7$ \\
\hline River to lake transect $(\mathrm{T})$ & June 2006 (7) & Hundreds of meters (horizontal) & $13.3 \pm 13.8$ & $1.33 \pm 0.81$ & $10.1 \pm 6.8$ \\
\hline $\begin{array}{l}\text { Small to large spatial } \\
\text { scale (EXP) }\end{array}$ & April $2008(20)$ & 1 to $1000 \mathrm{~m}$ (horizontal) & $4.8 \pm 1.4$ & $1.75 \pm 0.79$ & NA \\
\hline $\begin{array}{l}\text { North to south } \\
\text { transect (NS) }\end{array}$ & February $2010(6)$ & Kilometers (horizontal) & NA & NA & NA \\
\hline
\end{tabular}

profile) of the lake sediment (DP in Table 1). Samples ( 0.2 to $0.4 \mathrm{mg}$ of sediment) were frozen and stored at $-20^{\circ} \mathrm{C}$ until DNA was extracted.

Samples for assessing spatial variation in the sediment bacterial community were collected in 3 campaigns (see Table 1): (1) samples over $2 \mathrm{~km}$ at $300-$ $400 \mathrm{~m}$ intervals were collected along the transect of the inflowing river mouth to the middle part of the lake $(\mathrm{T})$; (2) variation over $1,10,100$, and $1000 \mathrm{~m}-$ three sediment cores were collected from each site (EXP) and (3) 6 samples were collected at $2600 \mathrm{~m}$ intervals along a transect along the lake in the $\mathrm{N}-\mathrm{S}$ direction (NS).

\section{Bacterial community composition}

Genomic DNA was extracted from the sediment samples using Zirconium beads $(0.1 \mathrm{~mm}$ diameter; burned at $500^{\circ} \mathrm{C}$ for $2 \mathrm{~h}$ ), phenol-chloroform-isoamyl alcohol (volumetric ratio PCI, 25:24:1, pH 8), $100 \mathrm{mM}$ pyrophosphate buffer (PP buffer, $\mathrm{Na}_{2} \mathrm{HPO}, \mathrm{pH}$ 8.3), and sodium dodecyl sulfate (SDS). Nucleic acids were precipitated with $\mathrm{NaOAc}$ and isopropanol overnight at $-20^{\circ} \mathrm{C}$. After centrifugation for $30 \mathrm{~min}$ at $13200 \times g, 4{ }^{\circ} \mathrm{C}$, the pellet was washed with $80 \%$ ethanol, dried under a vacuum, redissolved in $50 \mu \mathrm{l}$ Milli-Q water, and stored at $-20^{\circ} \mathrm{C}$.

The bacterial primers GM5-forward with $40 \mathrm{bp}$ GC-clamp and DS907-reverse were used to amplify an approximately $580 \mathrm{bp}$ fragment of the 16S rDNA suitable for subsequent DGGE analysis, including the highly variable V3 and V5 regions (Teske et al. 1996). PCR was performed using a thermocycler (Eppendorf) with each reaction taking place in $25 \mu \mathrm{l}$ reaction mixtures containing $200 \mu \mathrm{M}$ of each deoxynucleotide, $2.5 \mathrm{mM} \mathrm{MgCl} 2,400 \mathrm{ng}$ bovine serum albumin, $1 \mathrm{U}$ of Red Taq polymerase (SigmaAldrich), and $0.5 \mu \mathrm{M}$ of each primer. A 'touchdown' PCR was performed $\left(65\right.$ to $55^{\circ} \mathrm{C}$, step-down $0.5^{\circ} \mathrm{C}$ every cycle, followed by 15 cycles at $55^{\circ} \mathrm{C}$ ) as described by Brinkhoff \& Muyzer (1997). The success of the PCR was verified by running PCR products on $0.8 \%$ agarose gel and staining with ethidium bromide.

PCR-DGGE was performed as described by Muyzer et al. (1993). The PCR amplicons were run on a $6.5 \%(\mathrm{w} / \mathrm{v})$ polyacrylamide gel (acrylamide:bisacrylamide, $37.5: 1 ; 1 \mathrm{~mm}$ thick, polymerized for at least $2 \mathrm{~h}$ ) at $100 \mathrm{~V}$ for a maximum of $20 \mathrm{~h}$ at $60^{\circ} \mathrm{C}$ in $1 \times$ TAE using a CBS Scientific DGGE-2001 system. Different denaturing gradients between 35 and $70 \%$ ( $7 \mathrm{M}$ urea and $40 \%$ formamide [v/v] as $100 \%$ denaturants) were used, increasing in the direction of electrophoresis (from the top to the bottom). The gel was stained with 1000× SybrGold (Molecular Probes) for 30 min in $1 \times$ TAE buffer (pH 6.5) and the image was scanned with a variable mode imager (Typhoon Trio, Amersham Biosciences). To compare DGGE fingerprints, the gels were analyzed using ImageQuant TL software (Amersham Biosciences).

\section{Total number and production of sediment bacteria}

To determine bacterial abundance, $0.5 \mathrm{ml}$ of sediment fixed in glutaraldehyde (final concentration $1 \%$ ) was mixed with $2.9 \mathrm{ml}$ filtered (pore size $0.2 \mu \mathrm{m}$ ) lake water, and $0.6 \mathrm{ml}$ sodium pyrophosphate (500 mM) was added (Duhamel \& Jacquet 2006). The samples were sonicated for $5 \mathrm{~min}$ at $4^{\circ} \mathrm{C}$ (Bandelin Sonorex Digital 10P, $480 \mathrm{~W}$ ) and left to sediment under gravity overnight at $4^{\circ} \mathrm{C}$. The supernatant was diluted in DMSO at a volumetric ratio of 1:20, stained with SybrGreen I (final concentration $5 \mu \mathrm{M}$ ), and analyzed by flow cytometry (BD LSR II, excitation by solid state Sapphire L1 $488 \mathrm{~nm}$, band-pass filters $530 / 30 \mathrm{~nm})$. For quantification, $~ 50000$ particles of the internal standard (BD CountBrightTM absolute counting beads, diameter $7 \mu \mathrm{m}$ ) were added to each sample immediately before counting. Data were normalized to sediment dry weight (cells $\mathrm{g}^{-1} \mathrm{DW}$ ). 
To measure bacterial production (BP), $0.2 \mathrm{ml}$ of fresh sediment was transferred to a sterile $1.5 \mathrm{ml}$ Eppendorf tube and resuspended in $0.2 \mathrm{ml}$ sterile lake water (pre-filtered through GF/F glass fiber filter and autoclaved for $15 \mathrm{~min}$ at $121^{\circ} \mathrm{C}$ ) to form a homogeneous slurry at a 1:1 volumetric ratio (van Duyl \& Kop 1994, Haglund et al. 2003); triplicates were performed and 2 blanks were included each time. Sediment slurry sub-samples $(0.2 \mathrm{ml})$ were transferred to $2 \mathrm{ml}$ sterile safe-lock Eppendorf tubes and incubated with $\left[{ }^{14} \mathrm{C}\right]$-leucine (specific activity 10.8 GBq mmol ${ }^{-1}$, Hartmann Analytic, final concentration $0.5 \mu \mathrm{M}$ ). For blank measurements, $1.7 \mathrm{ml} 80 \%$ ethanol was added before the leucine. Incubation was carried out in the dark, with gentle shaking for $1 \mathrm{~h}$ at the in situ temperature. After incubation, bacterial incorporation of leucine into live samples was stopped by adding $1.7 \mathrm{ml} 80 \%$ ethanol. The samples were centrifuged $(10000 \times g, 5 \mathrm{~min})$, the supernatant was gently removed, and the sediment was resuspended in $1.7 \mathrm{ml} 80 \%$ ethanol. This centrifugationresuspension procedure in $80 \%$ ethanol was repeated once more. Thereafter, the sedimentethanol slurry was filtered through polycarbonate filters $(0.2 \mu \mathrm{m})$ and the filters were rinsed 5 times with ice-cold $5 \%$ trichloroacetic acid. The air-dried filters were transferred to sterile $2 \mathrm{ml}$ safe-lock Eppendorf tubes; $2 \mathrm{ml} \mathrm{NaOH}$ (1 M) was added and the suspension was heated for $2 \mathrm{~h}$ in a water bath at $100^{\circ} \mathrm{C}$ (the filters were completely dissolved). The samples were cooled and centrifuged (10000 $\times$ g, $5 \mathrm{~min})$. The supernatants $(1 \mathrm{ml})$ were transferred to scintillation vials containing $10 \mathrm{ml}$ scintillation fluid (Perkin Elmer OpiPhase HiSafe). Radioactivity was measured by liquid scintillation counting (Wallac Winspectral 1414). Data were normalized to sediment dry weight determined by desiccation $\left(105^{\circ} \mathrm{C}, 24 \mathrm{~h}\right)$.

\section{Statistics}

All statistical analyses were performed with the $\mathrm{R}$ package and its extensions ( $\mathrm{R}$ Development Core Team 2011). DGGE fingerprints were analyzed using a matrix of existing/missing bands (Jaccard similarity matrix, ordinated using correspondence analysis [CA]). To test the differences between layers, sites, or replicates, a between-groups CA was applied using layers, sites, or replicates as factors. The statistical significance of these groups was tested by a Monte Carlo permutation test (1000 replicates; Legendre \& Legendre 1998). Principal component analysis (PCA) was used to describe the variability of abundance and productivity of bacteria and the dry weight of the sediment. Relationships between DGGE fingerprints and other measured parameters were analyzed by canonical correspondence analysis (CCA) (ter Braak 1986). The statistical significance of CCA was tested by a Monte Carlo permutation test (1000 replicates).

Depth profiles obtained from various samples and analyzed on separate DGGE gels were analyzed using multiple factorial analysis (MFA) (Escofier \& Pagès 1994). The aim of this method is the simultaneous ordination of a series of $k$-data tables in which the same individuals (observations) are described by several sets of variables. The objective is to check whether similar structures can be extracted by different sets of individual measurements. As a first step, the influence of each set of variables is balanced in order to prevent any single set from dominating the construction of the MFA axes. This is done by reweighting the variables within each set according to the inverse of the first eigenvalue of the $k$ analysis. The first factor of MFA maximizes the projected inertia of all sets of variables. The outputs of MFA include the superimposed representations in the same space of individuals ordinated by each set of variables.

\section{RESULTS}

\section{Bacterial OTU richness}

Richness of abundant bacterial operational taxonomic units (OTUs) was estimated using the number of distinct bands on DGGE gels as a proxy. The total number of OTUs per gel ranged from 20 to 82 bands while the number of OTUs per sample (DGGE lane) ranged from 7 to 51 . The average number of OTUs decreased with depth (ANOVA, p < 0.05); the number of bands in the 0 to $2 \mathrm{~cm}$ layer ranged from 11 to 51 (median 38). In sediment layers deeper than $10 \mathrm{~cm}$, the number of bands ranged from 7 to 44 (median 18). OTU abundance also varied between sampling campaigns (Table 1) but their tendency to decrease in abundance with depth was consistent and did not change with campaign (MANOVA, $\mathrm{p}>0.05$ ).

\section{Horizontal variation of the community fingerprint on the 1 to $1000 \mathrm{~m}$ scale}

The community fingerprint based on the DGGE banding pattern was compared between samples collected from 4 sites separated by 1, 10, 100 and $1000 \mathrm{~m}$ from the area of presumably homogeneous 
sediment accumulation (Fig. 1). Communities were statistically similar in all samples and the variation was equal to the variation among triplicate samples taken from the same site (Monte-Carlo permutation test using between-groups analysis based on CA, replicates $\mathrm{n}=1000, \mathrm{p}>0.05$ ).

\section{Coast to mid-lake horizontal variation}

The community fingerprint changed significantly when samples were collected along the $\sim 2 \mathrm{~km}$ long river-lake transect (Fig. 1, T sampling stations, $\mathrm{n}=7$ ) from the inflowing river, river mouth, lake shore, and in the area with homogeneous lake sediment. The sediment in the river is more humic-rich (peat) than in the middle of the lake, where most of the sediment is sapropelic, while the sediment in the littoral zone was sandier (both sandy and sandy-gravelly types). The usual range of sediment DW from the upper $0.5 \mathrm{~cm}$ layer in the dominant sapropelic area was from 20 to $40 \mathrm{mg} \mathrm{g}^{-1}$ wet weight (WW), compared with $120 \mathrm{mg}$ $\mathrm{g}^{-1} \mathrm{WW}$ in the river bed and 175 to $<450 \mathrm{mg} \mathrm{g}^{-1} \mathrm{WW}$ in the sandy or sandy-gravelly sediment.

Direct gradient analysis (Fig. 2A) using the total number of bacteria (TNB), BP, and DW showed that the community fingerprint was statistically significantly related to these 'gradients' (Monte-Carlo permutation test of CCA, p <0.001). There was a clear gradient in $\mathrm{BP}$, increasing from the high-DW sediment towards the low-DW lake sediment, and community changes. BP was almost 7 -fold higher in the mid-lake sediment than in the peaty sediment in the river bottom $\left(2.63 \mu \mathrm{g} \mathrm{C} \mathrm{g}^{-1} \mathrm{DW}\right.$ in $\mathrm{T} 1$ versus $18.05 \mu \mathrm{g} \mathrm{C} \mathrm{g}^{-1} \mathrm{DW}$ in T7). A different pattern was observed for $\mathrm{TNB}_{\text {; }}$ the abundance of bacteria was high in the river sediment $\left(1.6 \times 10^{9} \pm 0.15 \times 10^{9} \mathrm{cells} \mathrm{g}^{-1}\right.$ DW), low in the sandy sediment in the littoral zone $\left(0.08 \times 10^{9} \pm 0.01 \times 10^{9}\right.$ cells g $\left.^{-1} \mathrm{DW}\right)$, and increased again with greater variation towards the middle of the lake $\left(1.8 \times 10^{9} \pm 0.64 \times 10^{9}\right.$ cells g$\left.^{-1} \mathrm{DW}\right)$. At the same time, total richness estimated as number of OTUs (DGGE bands) increased along the transect from the river mouth to the mid-lake, from 20 bands at Stn T1 to 40-44 OTUs in the mid-lake sediment (Stns T5 to T7).

\section{Kilometer-range spatial variation of profundal sediment}

The sampling campaign for analyzing spatial variation on a large scale (several kilometers) was car-
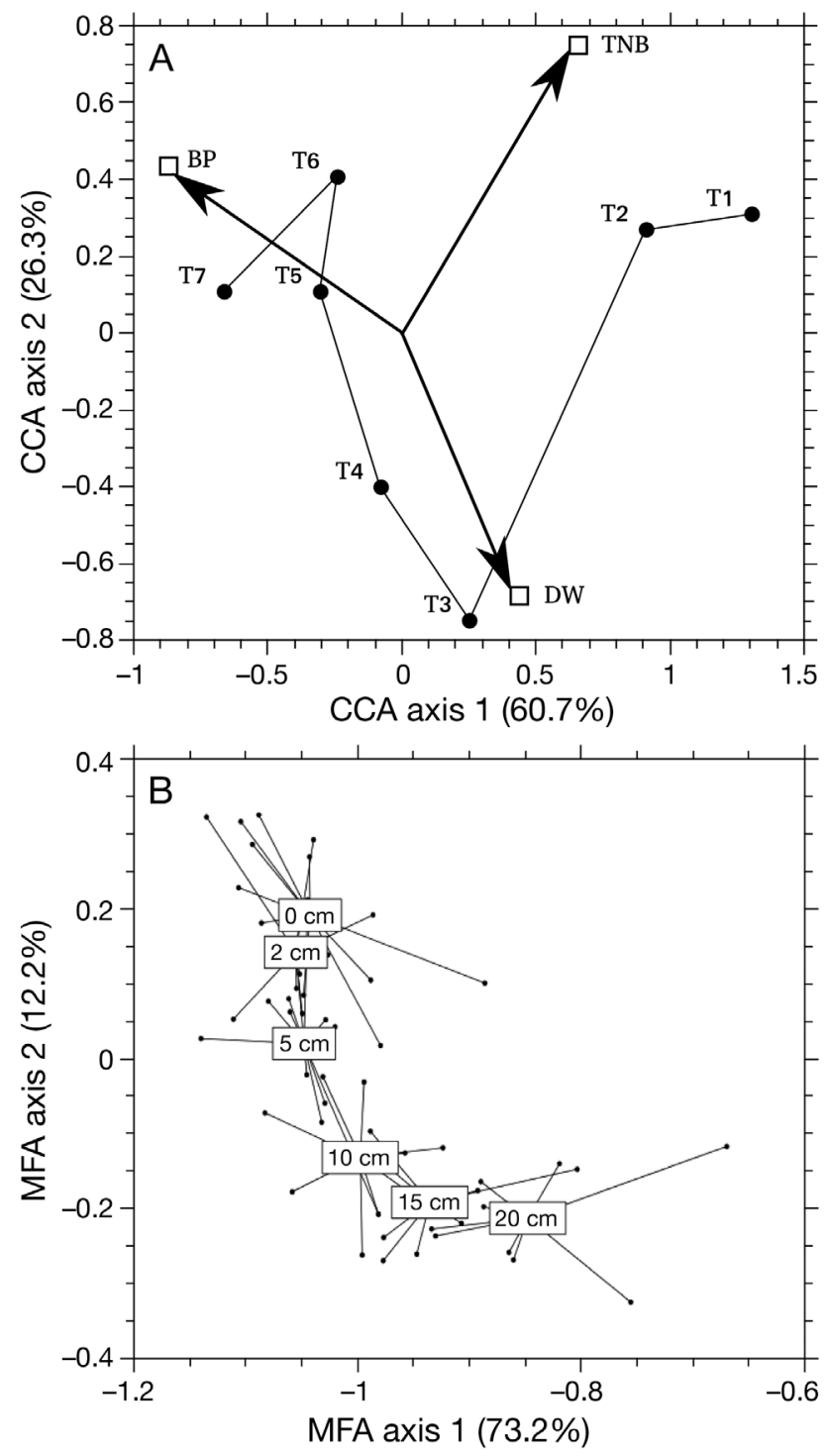

Fig. 2. Variability in gradients in the bacterial community fingerprint, described by the first 2 canonical correspondence analysis (CCA) ordination axes and given as a percent of the total variation. (A) Community at the sediment surface (uppermost $0.5 \mathrm{~cm}$ layer) along the river to lake (T) transect (- CCA sample scores are labeled according to Stn T1-T7 sampling points) and relationship to the independent variables total number of bacteria (TNB), bacterial production (BP), and dry weight (DW) gradients ( $\square$ ). (B) Variation of community structures in depth layers from 0 to $20 \mathrm{~cm}$, showing the superimposed structure of 6 depth layers with respect to each of the 10 sets of variables (sediment cores) on the 2 main axes of multiple factorial analysis (MFA). The 6 depth layers used in MFA are significantly different $(p<0.001)$

ried out along a $13 \mathrm{~km}$ transect from the southern part to the middle of the lake (Fig. 1, NS sampling stations). The community fingerprint did not change significantly within this transect (Monte-Carlo per- 
mutation test, between-groups analysis, $\mathrm{n}=1000$ replicates, $\mathrm{p}>0.05)$; the distance between sampling sites $(n=6)$ was $2600 \mathrm{~m}$.

\section{In-depth vertical variation}

To compare the vertical variation in community fingerprint within the surface sediment of a $20 \mathrm{~cm}$ thick surficial sediment layer, the sediment cores $(\mathrm{n}=10$, Stn T7 sampling point; Fig. 1) were sliced into six $1 \mathrm{~cm}$ thick layers $(0-1,2-3,5-6,10-11,15-16$, and 20-21 cm). All samples were taken from the same area of the lake in 2005 and 2006. The results of individual depth profile analyses were pooled together and analyzed by MFA. Fig. 2B displays the superimposed structure of the 6 sediment layers with respect to the 10 cores, as shown by the first 2 axes of the MFA. The first and second MFA components explain, respectively, 73 and $12 \%$ of the total inertia. Fig. 2B depicts relatively low within-group inertia, which indicates homogeneity in the structure obtained in each sediment score. The 6 layers are distributed along the second MFA axis; the 3 upper layers tend to cluster together in opposition to the 3 lower layers.

The strength of the between-group structure was tested using a Monte Carlo permutation test. The ratio of between-group variability was obtained using F-test statistics to compare the observed between-group variability measured on the first 2 axes of the MFA with that obtained after randomly shuffling the classes (1000 permutations). This procedure revealed a significant between-layers structure $(\mathrm{p}<0.001)$.

\section{DISCUSSION}

The aim of the present study was to analyze and compare the BCC and its variation in the upper sediment layer of a large shallow lake over horizontal and vertical scales. The lake bottom sediment undergoes frequent wind-induced resuspension during

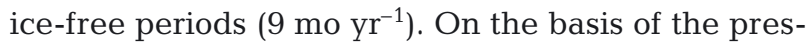
ent study we can conclude that the organic-rich and soft sediment (sapropel) surface was very homogeneous all over the lake. Vertically, this homogeneous surface layer extended from the sediment surface down to about 5-6 $\mathrm{cm}$ depth, while sediment from 10 to $21 \mathrm{~cm}$ proved to be different in BCC. This implies that below $10 \mathrm{~cm}$ depth, the bacterial community is not homogenized and shows more site specificity than the top $10 \mathrm{~cm}$ surface layer. The BCC in the organic-rich sediment showed a striking contrast from that in peaty, sandy, or sandy-gravelly sediments revealed in the river to lake transect study (Figs. 1 \& 2, Stns T1 to T4).

Obviously, the spatial variation in the $\mathrm{BCC}$ in the sediment of small deep lakes (Rissanen et al. 2011) or large deep lakes (e.g. Baikal, Constance, Kinneret; Pester et al. 2004, Shubenkova et al. 2005, Schwarz et al. 2007, Deutzmann et al. 2011) depends on the depth of the lake and, in the case of large lakes, the shape of the lake basin, leading to diverse conditions in the basins of these lakes. In studies of shallow and large lakes, the morphometry of which is more complex (such as Lake Taihu in China or Lake Balaton in Hungary), distinct bacterial communities have been observed (Liu et al. 2009, Tian et al. 2009, Szabó et al. 2011) in different basins with different sediment properties. Lake Võrtsjärv is more round in shape and the bottom areas are dominated by such sediments as organic (lake mud or sapropel), carbonaceous (lake marl), and terrigenous (gravel, sand, silt, clay) deposits. Sapropel is the most widespread sediment in Lake Võrtsjärv (Fig. 1). The upper layers of sapropel consist of liquid material (water content up to $95 \%$ ) and the organic matter content reaches 87 to $92 \%$ of dry matter (Haberman et al. 2004). Such sediment is very prone to resuspension during the icefree period, when the wind is the dominant cause of waves and currents, thus acting as the principal force in sedimentation. However, the area of Lake Vorrtsjärv is hundreds of square kilometers (average $280 \mathrm{~km}^{2}$ ), so it is comparable in size to Lake Balaton, having similar width (ca. $14 \mathrm{~km}$ ). Community heterogeneity in the sediment could be expected because larger distances are involved. Indeed, in Lake Vorrtsjärv the bacterial community DGGE fingerprint showed marked variation along the transect from the inflowing river mouth to mid-lake (Fig. 2). This transect covered various types of sediment; the first 2 samples (Stns T1 and T2 sampling points from the transect study; Fig. 1) were collected not from the lake but from the humic-rich peat sediment in the river bed. Also, samples from Stns T3 and T4 from the sandier littoral zone were distinct from the sapropel region. However, the area covered by clay sand or gravel is quite limited; over two-thirds of the lake bottom is soft and organic-rich sapropel. The bacterial community in this organic-rich sediment was not particularly abundant, but the TNB was higher than in the sandy sediments (CCA and Fig. 2A). In contrast, BP was high and therefore activity per cell is relatively high compared with other lakes (Tšertova et al. 2011 and references therein). Tšertova et al. 
(2011) found the BP in Lake Võrtsjärv to be 0.21 to $5.4 \mathrm{nmol} \mathrm{g}^{-1} \mathrm{DW} \mathrm{h}^{-1}$; this is comparable to a BP range of 0.27 to $3 \mathrm{nmol} \mathrm{g}^{-1} \mathrm{DW} \mathrm{h}^{-1}$ found in Lake Erken, which is both deeper and mesotrophic (Haglund et al. 2003).

Very little horizontal variation was observed in the $\mathrm{BCC}$ in the upper layer of sediments sampled within the organic-rich sediment area; the DGGE community fingerprint did not differ significantly between the $1 \mathrm{~m}$ and several kilometers scales. First we checked community profiles over scales from 1, 10, 100 and $1000 \mathrm{~m}$ using 3 replicates from each site. Because no variation was observed at any of these distances, a longer transect covering the southern compartment of the lake was sampled. A previous study comparing lake compartments has revealed that the plankton community, including the whole microbial loop in the southern lake ('macrophyte' lake), differs from the open lake region (Zingel et al. 2007). Therefore, greater horizontal variation in community structure was expected than at the $1 \mathrm{~km}$ range. In addition, sampling was carried out at the end of the ice cover period to allow some potential patchiness in community structures to develop, because during this time period no significant windinduced resuspension could occur. In an earlier study, seasonal succession of the BCC was observed in the upper $1 \mathrm{~cm}$ layer of sediment (Tšertova et al. 2011), which could lead to the development of spatial patchiness. However, no statistically significant difference was observed among samples collected along this $13 \mathrm{~km}$ transect, indicating very homogeneous conditions throughout the organic-rich sediment area in this lake.

The observed homogeneous community structure could result from limitations in fingerprinting techniques such as DGGE and similar methods (e.g. T-RFLP) that may fail to detect additional variations in the richness and diversity within environmental samples (Hughes et al. 2001). DGGE has been suggested as a good prescreening approach that could enhance and inform the application of next-generation sequencing (NGS) methods (Hanning \& Ricke 2011). On the one hand, the resolution of DGGE was sufficient to reveal seasonal variation within the same lake; however, it is clear that deep sequencing of 16S rDNA gene fragments using NGS technologies would enable rare species to be better resolved (Bowen et al. 2012). On the other hand, it is clear that current methods based on NGS technologies do not reveal the true diversity of complex microbial communities (Lundin et al. 2012), and more robust methods should be applied to estimate the true richness of environmental communities (Haegeman et al. 2013). The deep sequencing approach is more sensitive than DGGE for the detection of slight differences in the dominant community. The intensities of different DGGE bands derived from different bacterial species do not allow full quantitative conclusions to be drawn concerning the abundances of different bacteria because there could be an unknown PCR bias in the amplification of different templates (Teske et al. 1996). However, deep sequencing of PCR products suffers from a similar PCR bias. Therefore, simple fingerprinting techniques are not yet obsolete for rough screening of prominent variations in community composition, although they are not as powerful as NGS-based approaches for sequence-based identification and classification (Cleary et al. 2012, Pires et al. 2012).

The vertical distribution of bacterial community structure was determined from the sediment surface down to a depth of $20 \mathrm{~cm}$; no notable change was detected in the uppermost layers. Depth gradients in redox potential and oxygen concentration should have a consistent effect on the vertical distribution of bacterial communities. In relatively undisturbed sediments, i.e. deep lake bottom sediments, the environmental gradients are usually steep (Pester et al. 2004) owing to a pronounced change in redox conditions and/or oxygen concentration. Microbial communities usually follow these gradients because the geochemical processes shift vertically within millimeters at an aerobic sediment-water interface, leading gradually from oxygen consumption to nitrate, iron, and sulfate reduction in the processes of organic matter degradation. In situ measurements of oxygen concentration in Lake Võrtsjärv sediment suggested that the BCC should change within a few millimeters because oxygen disappears at a maximum of 5 to $10 \mathrm{~mm}$ (Tšertova et al. 2011). Instead, the community composition shifted deeper than $5 \mathrm{~cm}$ (Fig. 2B). Therefore, we assume that wind-induced resuspension is efficient at homogenizing the bacterial communities not only horizontally but also vertically along the upper $5 \mathrm{~cm}$ of the soft organic-rich sediment.

At first glance, widespread homogeneity of BCC is surprising considering the spatial scales, which should allow for some patchiness, and a strong enough redox gradient. In our study no artifact of undersampling was assumed because the samples were collected with various levels of replication. Instead, the strong disturbance and dispersal effect of the resuspension might account for the observed homogeneity in BCC. Similar homogeneity was 
bances, such as river sediment and landfill (Boon et al. 2000), and cultivated farm land soil (Bougnom et al. 2012).

One of the less-discussed drawbacks of the DGGE method is that independent gel images are difficult to compare. Usually, no more than 20 to 30 samples can be loaded onto a large DGGE gel, so direct comparisons are possible for only a limited number of samples. One way to circumvent this drawback is to shuffle samples for each comparison, as was done in the present study with the NS transect samples. This approach has also been used by others (Rösel et al. 2012). The NS transect samples were analyzed in 2 separate gels with 18 samples on each gel. These were used to analyze 3 upper layers from all sampling sites on one gel and 3 lower layers from all sampling sites on the other. Such shuffling allows us to compare sampling sites but not depth profiles from every single sampling site. Another option is to use standard lanes to normalize the gel using digital analysis (e.g. GelCompar); however, the results are not perfect with very complex gels that have more than 40 to 50 bands per lane. We propose an alternative statistical approach using the $k$-table ordination method of MFA. We used this approach to compare the depth profiles of 10 sampling sites originating from the DP study (Table 1), using 6 layers from each sampling, totaling 60 subsamples or DGGE lanes. The number of samples analyzed is no longer limited to the capacity of a single gel. MFA was chosen among several alternative $k$-table ordination methods such as STATIS or multiple co-inertia analysis. MFA is the most general approach for dealing with multiple tables linked by observations. It provides a particularly efficient and numerically stable solution for comparing structures among individuals induced by several sets of variables.

In conclusion, we observed the $\mathrm{BCC}$ to be very homogeneous over both centimeter and kilometer scales in areas of soft and organic-rich sediment sampled from a large, shallow lake. This homogeneous lake bottom is predominantly attributed to the accumulation of material that is repeatedly resuspended into the water column followed by re-settling. We hypothesize that intensive resuspension of the upper layer of soft sediment is the major factor that causes the homogeneous community distribution we observed even over long distances. The heterogeneity observed for the deeper layers below $10 \mathrm{~cm}$ could be explained by the fact that these layers are not mixed even during very intensive resuspension events. However, this hypothesis remains to be proven experimentally.
Acknowledgements. This work was supported by the Estonian Science Foundation (grant no. 6080 to V.K.), the European Regional Development Fund through the Center of Excellence in Chemical Biology, and the European Social Fund (Mobilitas Postdoctoral Research Grant MJD51 to A.K.). We acknowledge Jelena Kiprovskaja (University of Tartu, Institute of Technology) for laboratory assistance and all personnel at the Center for Limnology (Estonian University of Life Sciences) for providing laboratory space and a good working environment during the sampling campaigns.

\section{LITERATURE CITED}

Bloesch J (1995) Mechanisms, measurement and importance of sediment resuspension in lakes. Mar Freshw Res 46:295-304

Boon N, Marlé C, Top E, Verstraete W (2000) Comparison of the spatial homogeneity of physico-chemical parameters and bacterial 16S rRNA genes in sediment samples from a dumping site for dredging sludge. Appl Microbiol Biotechnol 53:742-747

Bougnom B, Greber B, Franke-Whittle I, Casera C, Insam H (2012) Soil microbial dynamics in organic (biodynamic) and integrated apple orchards. Org Agric 2:1-11

Bowen JL, Morrison HG, Hobbie JE, Sogin ML (2012) Salt marsh sediment diversity: a test of the variability of the rare biosphere among environmental replicates. ISME J 6:2014-2023

Brinkhoff T, Muyzer G (1997) Increased species diversity and extended habitat range of sulfur-oxidizing Thiomicrospira spp. Appl Environ Microbiol 63:3789-3796

Cleary DFR, Smalla K, Mendonça-Hagler LCS, Gomes NCM (2012) Assessment of variation in bacterial composition among microhabitats in a mangrove environment using DGGE fingerprints and barcoded pyrosequencing. PLoS ONE 7:e29380

Deutzmann JS, Wörner S, Schink B (2011) Activity and diversity of methanotrophic acteria at methane seeps in eastern Lake Constance sediments. Appl Environ Microbiol 77:2573-2581

> Duhamel S, Jacquet S (2006) Flow cytometric analysis of bacteria- and virus-like particles in lake sediments. J Microbiol Methods 64:316-332

Escofier B, Pagès J (1994) Multiple factor analysis (AFMULT package). Comput Stat Data Anal 18:121-140

> Güde H, Teiber P, Rolinski S, Sala M (2004) Comparison of production and degradation of organic matter at a littoral site of the prealpine Lake Constance. Limnologica 34: $117-123$

Haberman J, Nõges P, Nõges T, Pihu E, Kangur K, Kangur A, Kisand V (1998) Charactrization of Lake Võrtsjärv. Limnologica 28:3-11

Haberman J, Pihu E, Raukas A (2004) Lake Võrtsjärv. Estonian Encyclopaedia Publishers, Tallinn

Haegeman B, Hamelin J, Moriarty J, Neal P, Dushoff J, Weitz JS (2013) Robust estimation of microbial diversity in theory and in practice. ISME J 7:1092-1101

> Haglund AL, Lantz P, Törnblom E, Tranvik L (2003) Depth distribution of active bacteria and bacterial activity in lake sediment. FEMS Microbiol Ecol 46:31-38

$>$ Hanning IB, Ricke SC (2011) Prescreening of microbial populations for the assessment of sequencing potential. Methods Mol Biol 733:159-170 
Heinsalu A, Luup H, Alliksaar T, Nõges P, Nõges T (2008) Water level changes in a large shallow lake as reflected by the plankton:periphyton-ratio of sedimentary diatoms. Hydrobiologia 599:23-30

Hughes JB, Hellmann JJ, Ricketts TH, Bohannan BJM (2001) Counting the uncountable: statistical approaches to estimating microbial diversity. Appl Environ Microbiol 67:4399-4406

Kelderman P, Ang'weya RO, De Rozari P, Vijverberg T (2012) Sediment characteristics and wind-induced sediment dynamics in shallow Lake Markermeer, the Netherlands. Aquat Sci 74:301-313

Legendre P, Legendre L (1998). Numerical ecology. Elsevier, Amsterdam

Liu FH, Lin GH, Gao G, Qin BQ and others (2009) Bacterial and archaeal assemblages in sediments of a large shallow freshwater lake, Lake Taihu, as revealed by denaturing gradient gel electrophoresis. J Appl Microbiol 106: 1022-1032

Lundin D, Severin I, Logue J, Östman O, Andersson A, Lindström E (2012) Which sequencing depth is sufficient to describe patterns in bacterial $\alpha$ - and $\beta$-diversity? Environ Microbiol Rep 4:367-372

Muyzer G, de Waal EC, Uitterlinden AG (1993) Profiling of complex microbial populations by denaturing gradient gel electrophoresis analysis of polymerase chain reaction-amplified genes coding for 16S rRNA. Appl Environ Microbiol 59:695-700

Niemistö J, Holmroos H, Pekcan-Hekim Z, Horppila J (2008) Interactions between sediment resuspension and sediment quality decrease the TN:TP ratio in a shallow lake. Limnol Oceanogr 53:2407-2415

Pester M, Friedrich M, Schink B, Brune A (2004) pmoAbased analysis of methanotrophs in a littoral lake sediment reveals a diverse and stable community in a dynamic environment. Appl Environ Microbiol 70: 3138-3142

> Pires ACC, Cleary DFR, Almeida A, Cunha A and others (2012) Denaturing gradient gel electrophoresis and barcoded pyrosequencing reveal unprecedented archaeal diversity in mangrove sediment and rhizosphere samples. Appl Environ Microbiol 78:5520-5528

R Development Core Team (2011) R: a language and environment for statistical computing. Available at www. R-project.org

Rissanen AJ, Tiirola M, Ojala A (2011) Spatial and temporal variation in denitrification and in the denitrifier community in a boreal lake. Aquat Microb Ecol 64:27-40

Rösel S, Allgaier M, Grossart HP (2012) Long-term characterization of free-living and particle-associated bacterial communities in Lake Tiefwaren reveals distinct seasonal

Editorial responsibility: Rutger de Wit, Montpellier, France patterns. Microb Ecol 64:571-583

Schultz P, Urban N (2008) Effects of bacterial dynamics on organic matter decomposition and nutrient release from sediments: a modeling study. Ecol Model 210:1-14

Schwarz JIK, Lueders T, Eckert W, Conrad R (2007) Identification of acetate-utilizing Bacteria and Archaea in methanogenic profundal sediments of Lake Kinneret (Israel) by stable isotope probing of rRNA. Environ Microbiol 9: 223-237

> Shubenkova O, Zemskaya T, Chernitsyna S, Khlystov O, Triboi $\mathrm{T}$ (2005) The first results of an investigation into the phylogenetic diversity of microorganisms in southern Baikal sediments in the region of subsurface discharge of methane hydrates. Microbiology 74:314-320

Skoog AC, Arias-Esquivel VA (2009) The effect of induced anoxia and reoxygenation on benthic fluxes of organic carbon, phosphate, iron, and manganese. Sci Total Environ 407:6085-6092

Spears B, Carvalho L, Perkins R, Kirika A, Paterson D (2007) Sediment phosphorus cycling in a large shallow lake: spatio-temporal variation in phosphorus pools and release. Hydrobiologia 584:37-48

> Szabó G, Khayer B, Rusznyák A, Tátrai I, Dévai G, Márialigeti K, Borsodi A (2011) Seasonal and spatial variability of sediment bacterial communities inhabiting the large shallow Lake Balaton. Hydrobiologia 663:217-232

ter Braak CJF (1986) Canonical correspondence analysis: a new eigenvector technique for multivariate direct gradient analysis. Ecology 67:1167-1179

Teske A, Wawer C, Muyzer G, Ramsing N (1996) Distribution of sulfate-reducing bacteria in a stratified fjord (Mariager Fjord, Denmark) as evaluated by most-probable-number counts and denaturing gradient gel electrophoresis of PCR-amplified ribosomal DNA fragements. Appl Environ Microbiol 62:1405-1415

- Tian C, Tan J, Wu X, Ye W, Liu X, Li D, Yang H (2009) Spatiotemporal transition of bacterioplankton diversity in a large shallow hypertrophic freshwater lake, as determined by denaturing gradient gel electrophoresis. J Plankton Res 31:885-897

Tšertova N, Kisand A, Tammert H, Kisand V (2011) Low seasonal variability in community composition of sediment bacteria in large and shallow lake. Environ Microbiol Rep 3:270-277

> van Duyl FC, Kop AJ (1994) Bacterial production in North Sea sediments: clues to seasonal and spatial variations. Mar Biol 120:323-337

> Zingel P, Agasild H, Nõges T, Kisand V (2007) Ciliates are the dominant grazers on pico- and nanoplankton in a shallow, naturally highly eutrophic lake. Microb Ecol 53: 134-142

Submitted: October 31, 2012; Accepted: June 3, 2013

Proofs received from author(s): July 19, 2013 